\title{
Artigo
}

\section{Escrituras do grito em Antonin Artaud}

\author{
Carmela Tubino* \\ Simone Moschen \\ Universidade Federal do Rio Grande do Sul, Instituto de Psicologia, Porto Alegre, RS, Brasil
}

\begin{abstract}
Resumo: Este texto decanta da experiência de escuta-leitura da obra de Antonin Artaud e recolhe, nas construções do poeta, efeitos de testemunho acerca de um tempo de soltura entre voz e palavra, quando o que emerge é o grito. Este estudo acerca da voz e das tentativas de escritura do inominável conduz a uma pergunta auxiliar sobre o corpo. Nessa composição, destaca-se, a partir dos fios da psicanálise, lalangue - articulador teórico que enlaça corpo e palavra, voz e escrita. É a partir de lalangue que o artigo se inclina em direção à obra de Artaud para percorrer a travessia do grito desde o vazio da voz desancorada da palavra em um momento de queda do sujeito para um espaço/tempo de endereçamento e existência - existência que se sustentará corporificada na obra de Artaud.
\end{abstract}

Palavras-chave: pulsão, voz, Antonin Artaud, lalangue.

A tessitura deste texto tem seu início no encontro com a obra de Antonin Artaud, artista francês do fim do século XIX e início do século XX. Sua obra é composta de corpo e escrita: poeta, dramaturgo, ator... Artaud (re) cria na cultura um lugar para inscrever um nome. Ele será reconhecido por sua criação, pelas peças que passa a escrever e pela inovadora e subversiva escola de teatro que propõe. O Teatro da Crueldade, teorizado em obras como O teatro e seu duplo (1964/2012) e manifestos publicados, propunha-se incidir não apenas sobre o teatro, mas também sobre a linguagem e a poesia. Artaud engendra-se através de sua obra, que possui como matéria-prima o impossível que desconforta e desacomoda. Sua narrativa carrega a potência de transmissão que pode nos ajudar a seguir construindo a clínica. A experiência de leitura de sua obra pode se dar como se fosse uma Escuta-leitura que recolhe nas construções do poeta efeitos de testemunho acerca do momento de queda do sujeito, tempo de soltura entre voz e palavra, quando o que emerge é o grito.. Percorremos, para isso, um caminho de leitura que se pretende um ensaio de escuta da narrativa de Antonin Artaud depositada nas cartas escritas por ele, ao longo do seu período de internamento nos manicômios franceses entre os anos de 1937 e 1946. Leitura que toma as cartas como fio condutor, mas abre espaço a elementos de outras produções do poeta que se enlaçam à escrita das correspondências. Para compor esse texto, buscamos, nos fios da psicanálise, lalangue - neologismo proposto por Jacques Lacan como um articulador teórico que enlaça corpo e palavra, voz e escrita. É a partir de lalangue que este artigo se inclina em direção à obra de Artaud.

* Endereço para correspondência: carmelatubino@yahoo.com.br

\section{Escrituras do grito: uma escrita do impossível}

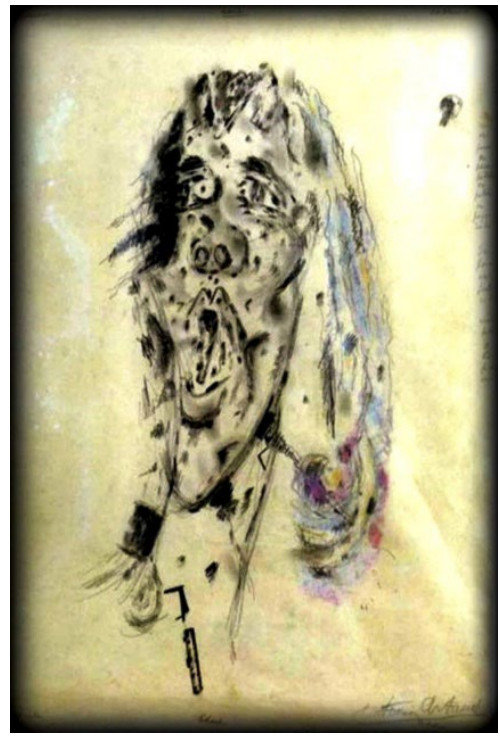

Figura 1. A angústialA cabeça azul (Antonin Artaud, 1946) ${ }^{1}$

"Por que mentir, por que tratar de colocar no plano literário algo que é o grito mesmo da vida, por que dar aparências de ficção ao que está com a substância inerradicável da alma, que é como o lamento da realidade?" (Artaud, 1979, p. 29). Artaud, em sua pergunta, desloca a leitura em duas direções. A primeira põe em relevo a ironia que carrega sua inquietação e o tom questionador que lhe é marca. $\mathrm{O}$ "porquê" parece portar uma crítica - não há ficção que recubra totalmente o inerradicável da alma. A segunda nos

1 Recuperado de https://glo.bo/39yupjD 
convoca a ler no literal sua frase, como uma pergunta. Há pergunta em Artaud: por que nos lançamos a escrever? Buscar uma escrita que tente portar um dizer, um dizer que transmita nossos inarredáveis, nossos lamentos, os gritos de cada um... A literatura, o teatro, as artes, isso que produzimos, por vezes, como contornos ao grito, ao Real que nunca será escrito - aí está sua potência. O Real como o que convoca o sujeito a seguir criando, pois trata-se, na fórmula de Lacan (1972-1973/1985), daquilo que não cessa de não se escrever. Real como registro que localiza o impossível, aquilo que não pode ser simbolizado e que, justamente por isso, demanda, incessantemente, um trabalho de inscrição.

Antonin Artaud inicia uma carta a Jacques Rivière, em 25 de maio de 1924, deslocando do plano da escrita literária isso que ganha letra a partir de um lamento da realidade - o grito. Na sequência dessa mesma correspondência, encontramos um Artaud comprometido a não mentir sobre a "essência da coisa...: uma enfermidade que arrebata a fala e a lembrança, que arranca o pensamento, ...uma verdadeira paralisia" (Artaud, 1979, p. 30). O grito que atravessa sua alma e sua carne todos os dias, como explica a Rivière, é inapreensível pela escrita literária. É de outra escritura que Artaud lança mão para dizer de sua angústia, para fazer do grito algum traço que, endereçado ao Outro, o salve da paralisia e da inexistência. Outro que, conforme elaborado por Lacan (2002, p. 39), em seu seminário $O$ desejo e sua interpretação, corresponde ao lugar do código, lugar referente ao tesouro da língua. Fala-se em lugar, pois Lacan toma como anteparo para pensar a constituição do sujeito, o grafo do desejo. Um gráfico, no qual situa posições que definem a posição-sujeito e todos os movimentos que compõe sua relação com o Outro.

É uma escrita do furo que irrompe em Artaud para dizer de seu grito e que pode mediar sua relação ao Outro. A noção de furo mostra aqui sua potência na medida em que ela indica, a um só tempo, o buraco - possibilidade iminente da queda - e a borda - possibilidade de armar algum anteparo frente ao que pode desmoronar. $\mathrm{O}$ furo, segundo explica Násio (1993), é esse espaço criado por uma borda pulsante. Borda e furo organizam as formulações sobre as zonas erógenas do corpo, os orifícios corporais - territórios pulsionais. O autorretrato que abre esse artigo carrega em seu traçado a questão que nos orienta: um traçado do grito como caminho para restituir palavras à voz. Em seu autorretrato, a imagem é feita de furos. A boca aberta desenha o grito, desenha a voz em estado puro. Grito silencioso que representa essa experiência de desarticulação entre a voz e a palavra. O sujeito tomado pelo buraco. Boca que devora e pela qual o sujeito, em sua relação com o Outro, também pode ser devorado. Superfície que se esboça na boca aberta de Artaud que, em cada traço, em cada palavra, em cada ato, parece colocar em cena o buraco:

E sempre escrevi para dizer que jamais disse nada, que não podia fazer nada, e que na realidade ao fazer algo não fazia nada. Toda minha obra foi construída e não podia ser de outro modo, sobre este nada, sobre esta hecatombe, esta mistura de fogos extinguidos, de gritos sufocados. (Artaud, 1977, p. 100)

Artaud, diante da insuficiência das palavras para transmitir o grito, "esses estados que nunca são nomeados, essas situações eminentes da alma" (Artaud, 2014, p. 210), que dão notícias sobre esse momento em que a voz perde a palavra, ensaia um uso outro da língua e da linguagem. Diante desse desenlace e da insuficiência das palavras, tal como ele as vivencia, propõe outra palavra, esta que se aproxima do efeito que elas adquirem nos sonhos, uma palavra anterior às palavras - expressão construída por Artaud em $O$ teatro e seu duplo - para falar do impulso psíquico secreto. "Escrevi um texto de comentários místicos de linguagem transcendental dos boêmios, e nele tentei abordar de modo concreto e direto o problema do Anticristo... Mandei esse texto a Jean Paulhan e tem por título KABHAR ENIS-KATHAR ESTI" (Artaud, 1981, pp. 107-108).

Artaud tentará propor uma nova relação com a linguagem em uma articulação do teatro com a poesia. Ele tomará o que de imagem e de sonoridade a linguagem possui para, da articulação desses elementos, tentar produzir efeitos singulares. As onomatopeias ganham destaque em sua escrita e irão compor texto, tentarão dizer disso que ao sentido e ao simbólico escapa. Artaud não trabalha com a palavra enclausurada, ossificada em seu significado, estabilizada em um a priori que exclui o sujeito. Ele busca, com sua produção, libertar a palavra, situá-la de forma a transmitir, em alto e bom som, a voz que suporta os interstícios do discurso e que, no corpo, se cifra. Segundo Artaud (1964/2012), "a obsessão pela palavra clara que diga tudo leva ao ressecamento das palavras" (p. 139).

É preciso admitir que a palavra se ossificou, que as palavras, todas as palavras, se congelaram, se enfurnaram em seu significado, numa terminologia esquemática e restrita. Para o teatro, tal como é praticado aqui, uma palavra escrita vale tanto quanto a mesma palavra pronunciada. $\mathrm{O}$ que leva alguns amantes do teatro a dizer que uma peça lida proporciona alegrias mais precisas, maiores do que a mesma peça representada. Tudo que diz respeito à enunciação particular de uma palavra, à vibração que ela pode difundir no espaço escapa-lhes, assim como tudo o que, por isso, é capaz de acrescentar ao pensamento. (Artaud, 1964/2012, pp. 138-139)

Artaud deseja desenfurnar as palavras, devolver sua potência que extravasa seu significado. Reconhece na função das palavras descongeladas essa possibilidade de enunciação que ocupa os espaços e atravessa o corpo. Os gestos, os sons irão compor o roteiro das peças. Os atores serão convidados ao improviso, a compor a cena com a outra cena. Artaud, sem conhecer a outra cena 
freudiana, coloca-a em ato em sua arte. Dessa forma, escrever o grito convoca a uma pluralidade de criações não à toa reconhecemos em seus desenhos elementos cruciais de sua empresa de dar registro ao grito.

Cada linha que traço em um desenho ou que escrevo em um texto representa em minha consciência um peso sem fundo que devo levantar em virtude da resistência da consciência de todos exceto de alguns amigos muito escassos como você... Para fazer cair por meio dos desenhos ou de poemas um muro inteiro de má consciência e permitir às almas chegar ao fim do que sempre tenham buscado: a verdadeira vida sobre o plano da verdadeira terra, contudo o que está à vista não é mais que uma mascarada. (Artaud, 1986, p. 74)

Os desenhos e a pintura podem ser pensados como um possível fundo, uma trama que ampara o sujeito em seus tempos de queda. Os traçados, as pinceladas oferecem borda ao vazio, contornos mais vivos e coloridos ao Real. Vale lembrar, aqui, de uma passagem de $O$ sinthoma, em que Lacan se põe a desenhar o nó borromeano, figuração topológica da indissociabilidade dos registros do Simbólico, Real e Imaginário:

O desejo de conhecer encontra obstáculos. Para encarnar esse obstáculo, inventei o nó... Se, por um lado, o nó é abstrato, ele deve, entretanto, ser pensado e concebido como concreto... pude provocar o que chamei de agitação e emoção, com essas figuras que vocês veem aqui mais ou menos substancializadas pelo escrito e pelo desenho. (Lacan, 1975-1976/2007, p. 37)

Artaud e Lacan, ambos ocupados em dar contorno ao Real, cada um com sua linha a produzir furos por onde se possa espiar esse algo a ser transmitido. $\mathrm{O}$ desenho, a escrita e a topologia operam como essa linha que precisa de paciência e tempo para inscrever uma abertura. Lacan busca na escrita e no desenho dar alguma substância ao Real. Na topologia, nos desenhos a partir do nó borromeano, da banda de Moebius, procura oferecer algum contorno ao Real. Estruturas tomadas da matemática e que se oferecem como suporte para pensar, para contornar o impossível. Em Milner (1987), encontra-se uma passagem sobre o trabalho dos poetas com o impossível, ou seja, com isso que comporta a falta e que não cessa de não se escrever:

O surpreendente é que o fracasso não seja absoluto e que um poeta se reconheça nisto que ele consiga efetivamente, senão preencher a falta, ao menos afetá-la. Na alíngua que ele trabalha acontece que um sujeito imprima uma marca e abra uma via onde se escreve um impossível a escrever. (p. 26)

Artaud e Lacan, ambos ocupados, a partir de diferentes caminhos, com diferentes desdobramentos em transmitir isso que diz do que não cessa de não se escrever, de não se desenhar, de não se pintar, de não se esculpir... mas que insiste em se fazer existir.

\section{Lalangue: o corpo da palavra}

Perguntar-me-ão que pensamentos são esses que a palavra não pode expressar e que, muito melhor do que através da palavra, encontrariam sua expressão ideal na linguagem concreta e física do palco... essa linguagem material e sólida através da qual o teatro pode se distinguir da palavra.

Ela consiste em tudo que ocupa a cena, em tudo aquilo que pode se manifestar e exprimir materialmente numa cena, e que se dirige antes de mais nada aos sentidos em vez de se dirigir em primeiro lugar ao espírito como a linguagem da palavra. (Artaud, 1964/2012, pp. 36-37)

A escrita da lalangue, conforme Caldas (2007), decanta em sua origem de um Outro ainda desorganizado, desarticulado da gramática ou de uma organização simbólica. Cai de um Outro portador de uma fala disjunta da estrutura da linguagem, como aponta a autora. A autora faz um recorte do seminário Mais, ainda, de Lacan, para destacar a diferença entre linguagem e lalangue, esta resultante do encontro com a língua materna e o objeto uma experiência que se inscreveria em um tempo anterior à fala articulada. A autora assinala que nesse encontro se produz a equivocidade e, desse equívoco, surge lalangue: constituída de ruídos, assonâncias, desses significantes desarticulados. Porge (2014) também se ocupa dessa noção: "neologismo introduzido por Lacan para designar a integral de equívocos de que é composta a língua dita materna para um sujeito, que determina o funcionamento do inconsciente, tanto em seus tropeços quanto em seu mergulho no gozo do corpo" (p. 79).

Desarticulado da gramática, fala disjunta, constituida de ruidos (Caldas, 2007), vale pelas ressonâncias, anterior à fala articulada (Artaud, 1964/2012), efeitos de gozo no corpo (Porge, 2014)... formas de dizer de lalangue que nos parece constituir a argamassa das construções de Artaud, nas múltiplas linguagens que se utilizou para enunciar suas questões. O poeta não conhecia esse neologismo cunhado por Lacan, lalangue, todavia, em sua obra, algo dele se transmite.

O domínio do teatro, é preciso que se diga, não é psicológico, mas plástico e físico. E não se trata de saber se a linguagem do teatro é capaz de chegar às mesmas resoluções psicológicas que a linguagem das palavras, se consegue expressar sentimentos e paixões tão bem quanto as palavras, mas de saber se não existe no domínio do pensamento e da inteligência atitudes que as palavras sejam incapazes de tomar e que os gestos e tudo o que participa da linguagem no espaço atingem com mais precisão do que elas. (Artaud, 1964/2012, p. 78) 
Artaud tem outra forma de fabricar palavras: "como se as palavras saíssem da noite escura da alma" (São João da Cruz, citado por Coêlho, 2013). "Algo está aí, e este algo não tem nome", como articula o autor, é o "verbo lascado", "assim como palavras furadas (não-sentido)" (Chaudanne, 2013,p. 7). Poéticas referências que carregam essa dimensão do furo da linguagem. $\mathrm{O}$ uso da palavra em Artaud trabalha para escrever esse furo e operar com ele. Em certa artesania, cria com a voz que sofre de excesso de encarnação e que se mantém aderida ao corpo, ao som. Podemos situar o furo como significante que orienta o encontro entre a linguagem artaudiana e lalangue. Lalangue é não-toda, carrega com ela o resto de um corpo que a diz, tal como as palavras que Artaud fabrica em sua obra. Artaud faz com lalangue, cria com o impossível, faz dele texto, desenho, criação que porta um dizer, imprime uma marca ao propor o Teatro da Crueldade, ao ler no corpo uma linguagem. Artaud, ao denunciar a precariedade das palavras e sua insuficiência, faz do furo a condição de sua arte. A arte, para ele, precisa dessa verdade que o vazio e a hecatombe sustentam.

Na empreitada de dizer o que há de não-palavra na palavra, Artaud (1964/2012) propõe uma poesia no espaço que se desdobra em um plano que não pertence estritamente às palavras, mas que se compõe através da música, da dança, das artes plásticas, dos gestos. Ele está ocupado em dar corpo à sua gramática, que tem no gesto sua matéria e sua cabeça. Gramática que se trama no corpo do ator e nas palavras tal como elas aparecem nos sonhos. Nas cartas, falava desse processo de reinvenção da língua inspirada pela vida, pelas sensações, pelo atravessamento do corpo nas palavras; uma língua ancorada no corpo, uma alíngua - lalangue.

Ao entrelaçar corpo e palavra, a obra de Artaud nos oferece elementos para pensar lalangue como esse "verdadeiro" - significante que sempre retorna em sua escrita referindo-se a tudo que escapa ao discurso articulado e se inclina na direção das questões inarredáveis da alma. E é nesse cenário onde Artaud busca sua "Palavra anterior às palavras" (Artaud, 1964/2012, p. 63). É com uma linguagem cifrada no corpo que Artaud faz teatro. Conforme sua colocação em $O$ teatro e seu duplo, a fonte dessa nova linguagem será buscada num "ponto mais recôndito e mais recuado do pensamento" (Artaud, 1964/2012, p. 129). Ao encontrar nas palavras um beco sem saída, o autor orienta um retorno ao gesto, ou seja, um retorno a isso que o corpo diz. E, nesse cenário, uma linguagem se articula entre o corpo e o que nele se cifra. Elaboração artaudiana que toca o neologismo lacaniano lalangue, que diz dessa língua que se dá pela fratura da palavra.

Não se trata de suprimir o discurso articulado, mas de dar às palavras a importância que elas têm nos sonhos. Quanto ao resto, é preciso encontrar novos meios de anotar essa linguagem, quer esses meios sejam aparentados com os da transcrição musical, quer se faça uso de uma espécie de linguagem cifrada... Por outro lado, essa linguagem cifrada e essa transcrição musical serão preciosas como meio de transcrever as vozes. (Artaud, 1964/2012, p. 107)

Lacan (1972-1973/ 1985), em suas colocações sobre lalangue, a diferencia de uma ferramenta que sirva à comunicação. O inconsciente é feito de lalangue. Algo que se aproxima, faz litoral às convocações artaudianas. A linguagem, segundo Lacan (1972-1973/1985), é o que se tenta saber da função de lalangue: "ela articula coisas que vão muito mais longe do que aquilo que o ser falante suporta de saber enunciado" (p. 190).

Iniciei-me na literatura escrevendo livros para dizer que me era totalmente impossível escrever; meu pensamento, quando tinha algo para dizer ou escrever, era aquilo que mais me negava. [...] avançando sempre à margem do que queria dizer de essencial e de enorme e que dizia eu jamais diria. Porém depois de transcorridos 20 anos me parecem extraordinários, não por seu êxito com isto, mas em relação com o inexpressável... Algo inexpressável expressado através de obras que apenas são catástrofes presentes. (Artaud, 1977, pp. 92-93)

Diante da insuficiência do discurso para situar sua elaboração, Lacan cria (lalangue ou alíngua), assim como o artista cria para nos falar da vida. Por vezes, a arte, como fala Artaud no recorte mencionado, contorna esse impossível de dizer que, para se fazer transmitir, por meio de uma artesania, revira a linguagem, estilhaça a palavra. O poeta entende que, por meio dos livros, o inominável trabalha para se escrever, passa do peito do poeta para o peito do leitor, do espectador. Aí, nessa travessia, Artaud reconhece o êxito de seu texto. O êxito não está em dizer o essencial ou o enorme, mas em tentar dizer pela obra o inexpressável. Lacan (1972-1973/1985) aponta que o recurso do analista está justamente nisso que fratura, que produz a falha na língua.

Seguir o fio do discurso analítico não tende para nada menos do que refraturar, encurvar, marcar com uma curvatura própria, e por uma curvatura que não poderia nem mesmo ser mantida como sendo como a das linhas de força, aquilo que produz com tal a falha, a descontinuidade. Nosso recurso é, na alíngua, o que a fratura. (Lacan, 1972-1973/1985, p. 61)

Com sua escrita, Artaud refratura, inscreve uma curvatura própria, aponta os limites do saber, o limite que o Real nos impõe. Sua linguagem concreta, essa que ele busca aproximar das palavras nos sonhos e que seria anterior às palavras articuladas, tem como efeito situar algo que resta como carta, letra - lettre, em francês, pode ser traduzido por ambas as palavras -, escrita e dirigida a seus leitores na busca por dar contorno a sua experiência-limite 
com o que se desprende da palavra. Nesse sentido, podemos pensar o pulsional na obra de Artaud, em sua tessitura, a partir de uma linguagem que acolhe lalangue...

\section{Entre o somático e o psíquico: ecos no corpo de que há um dizer}

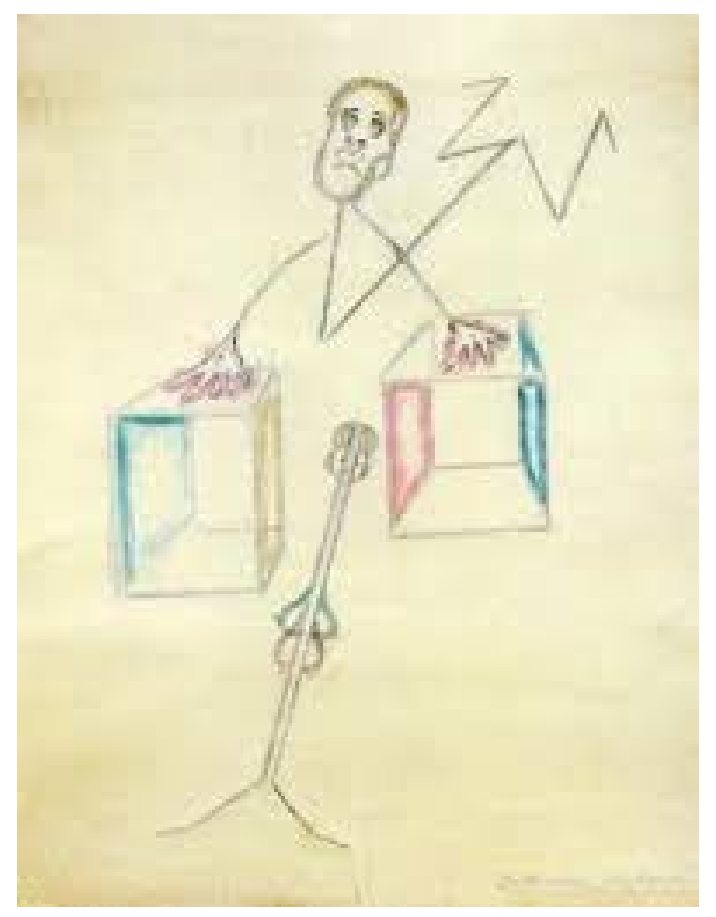

Figura 2. A morte e o homem, Antonin Artaud ${ }^{2}$

Tem que olhar este desenho uma vez mais para tê-lo visto uma primeira vez... Eu gostaria que ao olhá-lo mais de perto se encontrasse nele uma espécie de desprendimento da retina que tive ao separar o esqueleto de cima, sobre a página, como uma montagem para um olho. (Artaud, 1980, pp. 128-129, grifo nosso)

No desenho $A$ morte e o homem, realizado por Artaud, encontramos um caminho para uma aproximação ao conceito de pulsão. $\mathrm{O}$ autor propõe um homem desmontado. Entre vida e morte, um corpo se divide. $\mathrm{O}$ desenho, para ser lido, segundo orienta Artaud, precisa ser olhado em mais de um tempo. Algo precisa se destacar do olho para que o desenho seja visto. Olhar e visão são diferenciados em Artaud, que gostaria de tornar possível uma montagem para o olho. Ele parece nos dizer desses objetos que precisam se destacar do corpo para fazer sua função de transporte pulsional. Há uma montagem necessária para que o desenho seja visto. Montagem de algo que se dá pelo destacamento de um elemento do corpo.

2 Recuperado de https://bit.ly/2PjmNe5
Em 1905, no texto "Três ensaios sobre a teoria da sexualidade", Freud (1905/2006) refere que as pulsões são entendidas como parciais e como representantes psíquicos de uma fonte endossomática de estimulação que flui continuamente. A pulsão "é dos conceitos de delimitação entre o anímico e o físico" (Freud, 1905/2006, p. 159). Em 1915, no texto "As pulsões e seus destinos", Freud diferencia pulsão e estímulo, este proveniente do exterior. As pulsões, por sua vez, cuja origem se situa no interior do organismo, têm como característica se fazer presentes como uma força constante. A afirmação de que a pulsão é um conceito situado entre o somático e o psíquico é retomada. A pulsão é o representante psíquico dos estímulos que se originam dentro do organismo e alcançam a mente como uma medida de exigência de trabalho feito no sentido de estabelecer uma ligação entre as palavras e o corpo.

Coutinho Jorge (2011) destaca que o elemento central da concepção freudiana da pulsão é seu caráter parcial, especificado por uma fonte pulsional (as bordas do corpo) e pelo atingimento de um alvo que nunca se realiza de todo, restando sempre algo que é recolocado em circuito. $\mathrm{O}$ autor retoma os dois dualismos pulsionais propostos por Freud em sua teorização acerca da pulsão: o primeiro, que situa as pulsões sexuais e as pulsões de autoconservação; o segundo, referente à pulsão de vida e à pulsão de morte. Freud (1920/2006), em "Além do princípio do prazer", situa a pulsão de morte como esse mais além do princípio do prazer. A formulação da pulsão de morte na teoria freudiana, segundo Coutinho Jorge (2011), abre espaço para especificar duas características pulsionais: seu caráter conservador, restitutivo, e seu aspecto repetitivo. Ao final do texto de 1920, Freud refere que a pulsão de morte exerce essa tendência de um retorno ao estado inorgânico e que o princípio do prazer, por sua vez, serviria à pulsão de morte, na medida em que sua função é conservar a quantidade de excitação constante no aparelho psíquico, mantendo a excitação o tão baixa quanto puder. Ainda em "Além do princípio do prazer", ele irá trabalhar a repetição, um dos aspectos inerentes à pulsão, a partir dos sonhos que ocorrem nas neuroses traumáticas, das brincadeiras infantis e do fenômeno da transferência: "As manifestações de uma compulsão à repetição... apresentam em alto grau um caráter pulsional e, quando atuam em oposição ao princípio do prazer, dão a aparência de alguma força demoníaca em ação" (Freud, 1920/2006, p. 46).

Importa-nos destacar esse "demoníaco", tal como Freud (1920/2006) aponta, essa força que convoca para a compulsão à repetição e que nos relança à obra de Artaud e sua tentativa de escrever o grito. Lacan (1964/1998), no seminário Os quatro conceitos fundamentais da psicanálise, irá falar da compulsão à repetição a partir da tiquê e do autômaton. A tiquê se refere à insistência do Real. O autômaton está, por referência, às tramitações pelo Simbólico. O Real, para Lacan (1964/1998), é o que vige por trás do autômaton, o que arrasta consigo o sujeito, é esse inassimilável que se dá a ver pela forma 
do trauma. O Real, isso que aparece na função de tiquê, pode ser representado pelo acidente. Essa formulação nos remete à produção de Artaud, sua incessante tentativa de dizer do instante do acidente, da irrupção e dos estados inomináveis da alma. Algo em Artaud não cessa de não se escrever, encenar, desenhar, gritar... "O real, é para além do sonho que temos que procurá-lo - no que o sonho revestiu, envelopou, nos escondeu, por trás da falta de representação" (Lacan, 1964/1998, p. 61).

A pulsão, segundo Lacan (1964/1998), é concebida como efeito da demanda do Outro, efeito da linguagem sobre o sujeito desde seus primeiros momentos. Essa ação do Outro sobre o sujeito se dá a ver nos contornos que assumem as bordas do corpo, o que Freud chamou de zonas erógenas. A pulsão, conforme destaca Porge (2014), relança a questão acerca do limite entre a borda, o corpo, a linguagem e lalangue. A pulsão desenha um percurso circular em que o vaivém se faz fundamental para marcar os contornos das zonas erógenas.

Algo que sai de uma borda que reduplica sua estrutura fechada, seguindo um trajeto que faz retorno, e de que nada mais assegura a consciência senão o objeto, a título de algo que deve ser contornado... Esta articulação nos leva a fazer da manifestação da pulsão, o modo de um sujeito acéfalo, pois tudo aí se articula em termos de tensão, e não tem relação ao sujeito senão de comunidade topológica. (Lacan, 1964/1998, p. 171)

O traçado foi nomeado por Lacan (1964/1998) como traçado do ato - parte de uma borda corporal e a ela retorna, desenhando o contorno do objeto e, concomitantemente, estabelecendo uma zona erógena. Na tramitação do circuito pulsional, Freud (1915/2006) encontrará a constância de três tempos, o que Lacan enunciará como relativos a três formas gramaticais: ativa, passiva e reflexiva: "A gramática vetoriza o trajeto da pulsão, no limite do corpo e de lalangue" (Porge, 2014). A contagem desse terceiro tempo por Lacan, o fazer-se, é uma forma de reconhecer que o vai e vem dos outros dois tempos não escreve um círculo redutível a um ponto. Contudo aponta para um furo, esse traçado contorna um vazio. É esse terceiro tempo que parece permitir que o circuito se mantenha.

A pulsão invocante será considerada, ao longo da construção lacaniana, a pulsão mais próxima da experiência do inconsciente. Artaud (1964/2012) se refere à "música da palavra" (p. 140) - referência - que fala diretamente ao inconsciente. Atribui valor ao que se percebe pelos ouvidos, permitindo-nos avançar na articulação entre corpo e linguagem, entre pulsão e lalangue: "as pulsões são, no corpo, o eco do fato de que há um dizer". Lacan insiste de que, para que esse dizer ressoe, para que consoe, é necessário que o corpo lhe seja sensível. E o corpo se faz sensível através de seus orifícios, dos quais o psicanalista indica a especificidade do ouvido - por ele não poder se tapar, se fechar. "O teatro oriental soube conservar um certo valor expansivo das palavras, uma vez que na palavra o sentido claro não é tudo, mas sim a música da palavra, que fala diretamente ao inconsciente" (Artaud, 1964/2012, p. 140, grifo nosso).

As formulações de Artaud nos convidam a ouvir as palavras por meio do que entra pelos ouvidos, do que entra pelo "aspecto físico afetivo" (Artaud, 1964/2012, p. 140): seu ritmo, sua música, seu além/aquém do sentido. Ouvi-las em sua ligação com o que bordeia o corpo, o físico em seu enlaçamento com isso que se ouve do Outro. As palavras, para serem ouvidas, devem estar relacionadas "aos movimentos físicos que lhe deram origem" (Artaud, 1964/2012, p. 140), a isso que extravasa o que gramaticalmente falam e que se transmite no suporte sonoro, em gestos, em algo que decanta do efeito de um endereçamento. Artaud, em suas considerações, faz pensar sobre um dizer que pulsa, que se faz passar por entre sons, imagens, gestos. Há na palavra algo a ser transmitido por sua musicalidade que fala ao inconsciente; algo que se escande, como na música; algo que se desliga da gramática. Artaud se refere à musicalidade, essa linguagem por entre as palavras que se cifra nos suportes das notas musicais e que ali se enuncia em letras outras, lalangue.

\section{Do que se destaca em voz: o objeto da pulsão invocante}

"O que é que a voz nos ensina como tal, mais além do discurso que ela sustenta no telefone?" (Lacan, 19551956/2002, p. 412). Não se trata da voz que escutamos, que materializamos no suporte sonoro, mas de uma voz que está reduzida "ao ponto puro onde o sujeito não pode tomá-la senão como impondo-se a ele" (p. 412). A voz, como objeto $a$, é isso que cai da esquize entre o ouvido e a voz; é resultante de uma disjunção entre som e voz. A voz, como objeto, materializa-se por intermédio do som, mas está para além dele. No seminário As psicoses, Lacan opera, por meio de bom exemplo, com essa esquize entre som e voz trazida por Caldas (2007): "se o surdo-mudo ficar fascinado pelas linhas das mãos de seu interlocutor, ele não registrará o discurso veiculado por essas mãos" (Lacan, 1955-1956/2002, p. 158). "Linguagem não é vocalização", profere Lacan (1962-1963/2005, p. 299) em uma das lições do seminário $A$ angústia.

A voz, para Porge (2014), se destacaria do objeto sonoro, sofreria esse corte, separação do sujeito diante da falta no Outro no que ele propõe como Estádio do eco. Para o autor, o "Estádio do eco,... a borda turbilhonante do silêncio do sujeito" (Porge, 2014, p. 126), estaria ligado a uma passagem do grito ao apelo e à fala, tendo a voz como resto. A voz, nessa travessia, se torna esse impossível de recuperar. Resto em torno do qual a pulsão dá voltas. Um resto do qual, conforme refere Porge (2014), só podemos apreender o eco. De acordo com o autor, como objeto $a$, a voz se destaca das representações sensoriais. Lacan (1963/2005), no seminário Os nomes-do-pai, recupera essa proposição de que a voz como objeto da pulsão não é uma questão de timbre. A voz não é o dizer. $\mathrm{E}$ a voz, como qualquer objeto pulsional, não possui uma 
imagem especular. Além do corte, a voz se coloca como objeto da pulsão invocante por inscrever um circuito entre dois orifícios corporais - boca e ouvido. Aí se estabelece o circuito da pulsão invocante. Porge (2014), recuperando uma formulação de Lacan do seminário Os nomes-do-pai, fala sobre a dimensão temporal da voz, do objeto $a$ : ao longo de uma duração de tempo, a fala sofre pausas, passa por silêncios, aí nos intervalos a voz ressoa.

Porge (2014) destaca três tempos da pulsão invocante que estão conectados a duas séries: a série da boca, do falar ou do chamar, e a que sai da orelha, o escutar, o ouvir. A primeira assim se estrutura: falar ou chamar; ser falado ou ser chamado; fazer-se falar ou fazer-se ser chamado. E a segunda, que sai da orelha, desdobra-se dessa forma: ouvir ou escutar; ser ouvido ou ser escutado; fazer-se ouvir, fazer-se escutar. Temporalidades que permeiam momentos da fala de Artaud acerca dos percursos que seu dizer percorre a partir de seu corpo até chegar ao espectador. Em sua produção, há a construção de uma travessia por onde flui uma mensagem que se lança das cartas, do corpo, do grito, da arte, até "tocar o peito do espectador".

Da vista ao ouvido, do intelecto à sensibilidade, do gesto de uma personagem à evocação dos movimentos de uma planta através do grito de um instrumento. Os suspiros de um instrumento de sopro prologam as vibrações de cordas vocais, com tal senso de identidade que não sabemos se é a própria voz que se prolonga ou o sentido que, desde os primórdios absorveu a voz. (Artaud, 1964/2012, p. 58)

Artaud propõe a escansão como forma de recortar um ritmo para seus poemas, ritmo que é singular na medida em que cada leitor encontrará o seu. Nesse fazer-com os seus poemas algo se recorta em cada leitura. Em Artaud, leitura é ato. Lacan, citado por Porge (2014), refere que é na escansão da fala que se encontra a voz em sua dimensão de objeto $a$. Escansão que produz intervalo entendido como o vazio inscrito pela falta no Outro, pelo enigma de seu desejo e de seu gozo. Diante da existência dessa falta no Outro, algo pode se destacar do sujeito, como, por exemplo, a voz. É em um espaço vazio, produzido a partir de um corte, ou seja, de uma escanção, que a voz pode surgir em sua dimensão de objeto $a$.

Encontramos em Porge (2014) a marcação, pela topologia lacaniana, do trajeto da pulsão invocante que tem como referencial a superfície moebiana em que se constitui a garrafa de Klein. Um trajeto em duplo laço, onde dois orifícios se articulam - boca e orelha; falar e ouvir - bordeando um vazio. É a garrafa de Klein que permite a Lacan figurar a voz em sua condição de objeto $a$, esse objeto que não tem representação, destacado da materialidade sonora que se dá no movimento de boca à orelha. Em O aturdito, Lacan (1972/2003) escreve que a topologia se faz necessária para demonstrar o Real. Ela permite demonstrar que há cortes no discurso que modificam a estrutura: "A topologia não foi feita para nos guiar na estrutura. Ela é a estrutura - como retroação da ordem de cadeia em que consiste a linguagem" (Lacan, 1972/2003, p. 485). Em suas palavras, o que a topologia ensina é o vínculo necessário que se instaura entre o corte e o número de voltas que ele comporta para se obter uma mudança na estrutura. A leitura de Artaud permite testemunhar a potência da arte, assim como a da topologia, de escrever esses cortes estruturantes na constituição do sujeito. Podemos testemunhar dos pontos de contato entre algumas das questões que animam Lacan e Artaud ao colocarmos em série Lacan, com a garrafa de Klein; Artaud, com o autorretrato; e Munch, com O grito.

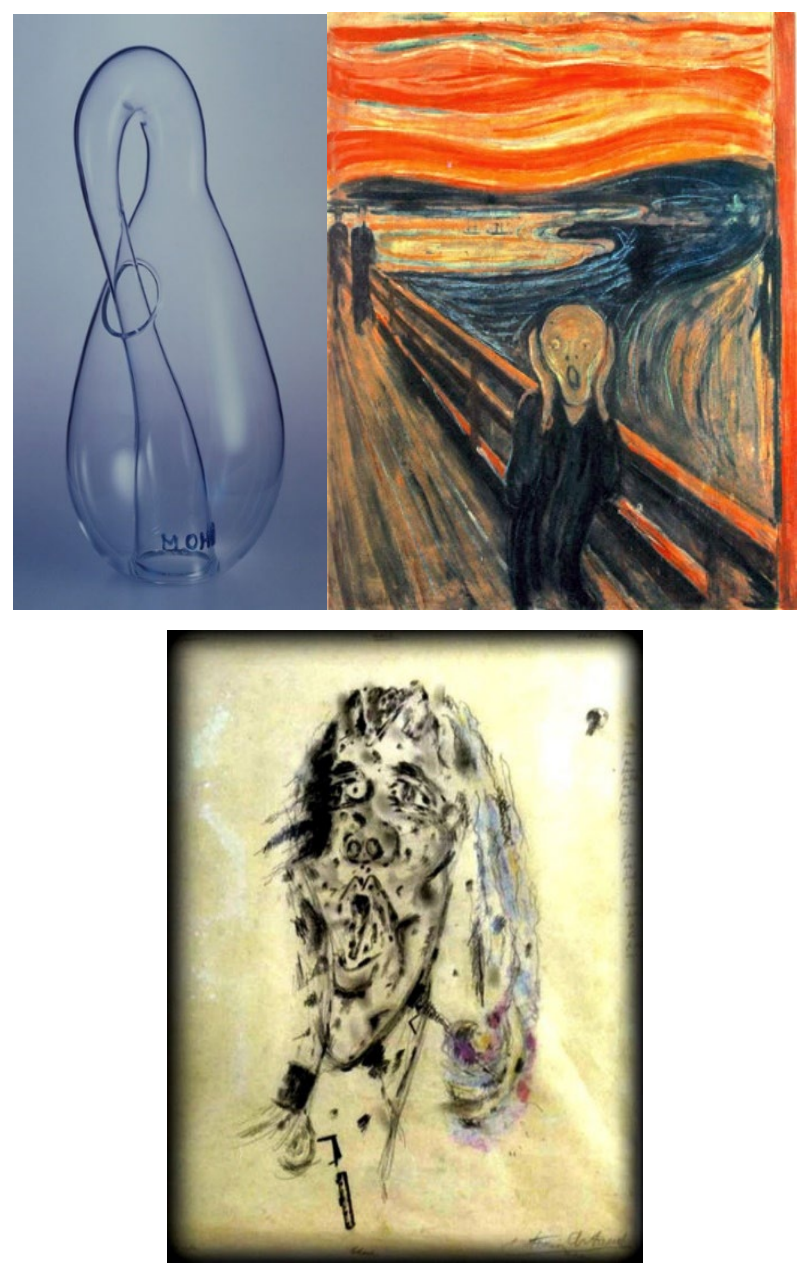

Figura 3. Garrafa de Klein ${ }^{3}, O$ grito (Edvard Munch, 1893$)^{4} \mathrm{e}$ A angústialA cabeça azul (Antonin Artaud, 1946)

\section{O grito e o limite da palavra}

Artaud parecia estar ocupado em dar voz ao grito que não está materializado no som, esse que passa de boca ao ouvido e que toca o peito: algo que amarra corpo

\footnotetext{
3 Recuperado de https://bit.ly/3dlqvM4

4 Recuperado de https://bit.ly/3cHJq4H

5 Recuperado de https://glo.bo/39yupjD
} 
e lalangue. Algo entre o somático e o psíquico também circulava nas elaborações do artista, circuito pulsional que, no teatro, fazia-se ato e texto. A verdade, para Artaud, está no impossível que o grito evoca, está na "Palavra anterior às palavras". Para Quilici (citado por Coêlho, 2013), o grito não é necessariamente a emissão de um som inarticulado e estridente. A palavra pode ser palavra-grito quando é resposta primeira ao impacto ordinário - essa apreensão da vida como crueldade. A palavra-grito irrompe em Artaud desse impacto originário e pode abrigar seus efeitos, garantindo a conexão entre a expressão e a vida.

Lacan (1968-1969/2007) irá falar, no seminário De um Outro ao outro, sobre o grito verdadeiro da angústia, o grito vazio, o grito mudo. Em sua fala sobre o verdadeiro, interroga-se sobre o que poderia o Outro responder ao sujeito nesse momento do grito. Nada, exceto na direção da fabricação do objeto $a$. Vemos em Artaud a ressonância da questão colocada por Lacan. "Para descrever o grito com que sonhei, para descrevê-lo com palavras vivas, com palavras apropriadas e para, boca a boca e respiração contra respiração, fazê-lo passar não para o ouvido, mas para o peito do espectador" (Artaud, 1964/2012, p. 171).

Esta carne que não se toca mais na vida, esta língua que não chega a ultrapassar sua casca, esta voz que não passa mais pelas vias do som... tudo isto que faz minha múmia de carne fresca dá a deus uma ideia do vazio em que a necessidade de ter nascido me colocou. (Artaud citado por ASSOUN, 1999, p. 135)

Assoun (1999) irá tomar o fragmento do texto artaudiano para pensar uma voz que não passa pelas vias do som, algo que subverte a ideia definidora de objeto sonoro e que redireciona a pesquisa para a dimensão da voz como objeto da pulsão. Lacan (1968-1969/2007) menciona que esse grito, na elaboração freudiana, estará associado a "alguma coisa absolutamente primária" e ao Nebenmensch, o próximo - forma que Freud encontrou de nomear a alteridade situada no semelhante que acolhe e sustenta o bebê em seu desamparo primordial. "É no próprio silêncio que se centra esse grito, que surge na presença desse próximo" (Lacan, 1968-1969/2007, p. 219). Artaud, em sua obra $O$ teatro e seu duplo, fala que o grito que lança na peça o Teatro do Séraphin é aquele que evoca "o buraco do silêncio, de silêncio que retrai":

Ora, o grito que acabo de lançar evoca primeiro um buraco de silêncio, de silêncio que se retrai, depois o barulho de uma catarata, um barulho de água, está na ordem, pois o barulho está ligado ao teatro... Isso significa que quando represento meu grito deixou de girar em torno de si mesmo, mas desperta seu duplo de forças nas muralhas do subterrâneo. E esse duplo é mais do que um eco, é lembrança de uma linguagem cujo segredo o teatro perdeu. (Artaud, 1964/2012, pp. 170-171)
Grito que, quando endereçado ao público, ganha um duplo que transcende o eco e se faz lembrança. Em sua poética, Artaud fala sobre uma linguagem esquecida, evocada por esse duplo do grito que só acontece quando representado, quando endereçado. Uma linguagem de um tempo anterior que pode ser evocada quando nos reportamos ao grito. "O grito é o limite da voz. Ele rasga a garganta", elabora Porge (2014, p. 117). Nessa travessia entre voz e fala, o grito aparece como esse chamamento arcaico anterior às palavras que pode fazer laço entre a criança e aquele que a acolherá em seu desamparo.

Do desamparo, nasce o grito em um tempo ausente de palavras. É pelo grito e pelos sons que sobrevêm, com as modificações corporais que observamos, os caminhos do bebê até sua entrada na linguagem. É se tornando apelo que o grito entrará no circuito pulsional. Entre o grito e a voz, conforme situa Porge (2014), há um tempo de passagem pelo jogo de vocalizações, os balbucios, os gorgolejos, as lalações. O Estádio do eco, segundo as formulações de Porge (2014), estaria ligado ao momento de passagem do grito ao apelo e à fala, produzindo a voz como objeto resto.

Entre a voz e seu eco desliza o silêncio. Silêncio, voz e grito formam, de acordo com Porge (2014), um nó. O grito manterá sua ligação ao corpo, como dito anteriormente, do corpo que goza, ali onde lalangue faz texto. Essa linguagem de gozo intervém sob a forma de lalangue, primeira marca do ser falante: "Por isso em Artaud irrompe cada vez com mais força o grito. $\mathrm{O}$ grito é a unidade, o que irrompe é a unidade, um mundo, uma sociedade, um corpo que não representa nada. O grito é a ruptura da linguagem" (Oscar del Barco, 1979, p. 24).

Afirmação que conversa com as proposições de Lacan (1955-1956/2002) quando refere que o grito, "a borda mais extrema da participação motora da boca na fala" (p. 162), é a coisa pela qual a palavra falada se combina com a função vocal absolutamente a-significante. Nada, silêncio absoluto que se segue ao grito. O grito que vem depois do silêncio é mudo, ecoa em uma voz áfona, que não passa, como refere Artaud em suas elaborações, pelas vias do som. Grito que ecoa no corpo, que toma o corpo como seu anteparo. Grito e silêncio, nesse sentido, parecem estabelecer um elo, ambos apontam para um vazio da palavra. O grito, por conseguinte, ao se extinguir, causaria o silêncio. E o sujeito, por sua vez, surgiria nesse intervalo.

De acordo com Porge (2014), o silêncio pode ressoar quando o grito o escava, referindo-se à garrafa de Klein para pensar o furo do grito. Assim como Lacan (19641965), Porge (2014) também recupera a tela de Edvard Munch, $O$ grito, para ilustrar suas elaborações. O autor segue com uma pergunta que aqui se faz interessante: "O que pode ser melhor que o silêncio de um quadro para falar do grito?" (Porge, 2014, p. 115). Interessante na medida em que desloca a questão do grito e da voz para algo que se diferencia do som, que ecoa no anteparo da linguagem, em lalangue. 
Esta imagem é onde a voz se distingue de toda a coisa modulante, pois é o grito que a faz diferente diante de todas as formas, as mais reduzidas da linguagem, é a simplicidade, a tradução do aparato posta em causa. Aqui a laringe não é mais que uma seringa. A implosão, a explosão. O corte, falta. O grito, nos dá talvez a segurança desse algo por onde o sujeito não aparece mais do que como significado dessa abertura (béance) aberta anônima, cósmica, marcada em um canto de duas presenças humanas. (Lacan, 1964-1965, p. 58, tradução nossa)

Essa imagem, para Lacan, ajuda a pensar como a voz se distingue de toda modulação. Freud, como recupera Lacan na sequência da sua aula, articula o buraco do grito ao Nebenmensch (o semelhante, o próximo que socorre). Esse buraco intransitável, como refere Lacan (1964-1965), "marcado no interior de nós mesmos e ao qual não podemos mais que nos aproximar apenas" (p. 59); "ora, o grito que acabo de lançar evoca primeiro um buraco de silêncio, de silêncio que se retrai, depois o barulho de uma catarata, um barulho de água, está na ordem, pois o barulho está ligado ao teatro" (Artaud, 1964/2012, p. 170).

Melman (2008), em uma conferência que versou sobre a paranoia, traz uma pergunta interessante: "quando é que vocês se põem a gritar? Não se grita em qualquer momento, se grita quando o significante não serve para nada. Quando ninguém quer escutá-lo, então, como último meio resta justamente ouvir a voz em estado puro" (pp. 55-56). O autor, nesse sentido, explica que o grito, o milagre do uivo, se dá quando todo o sistema - a saber, sua relação com a linguagem - parece poder desabar. O grito, nesse tempo de injunção, seria a única maneira de sustentar a potência da voz, a única forma de o sujeito se proteger da angústia do desaparecimento, do desabamento do mundo. Couso, Karoty, Aguirre e Mazza (2010) apontam que a voz, na sua condição de objeto da pulsão, pode se desprender da cadeia significante. Assim, a voz pode aparecer como som puro, separada da amarração à palavra. Aqui poderíamos pensar na irrupção da crise, injunção que Melman (2008) destaca como o tempo do urro. Nesse sentido, o som desprendido da palavra é tomado pelo sujeito como um puro signo de uma significação absolutizada. Algo inassimilável, como elaboram os autores mencionados.
Para gritar não preciso força, preciso apenas fraqueza, e a vontade partirá da fraqueza, mas viverá, a fim de recarregar a fraqueza com toda a força de reinvindicação. Agora posso encher meus pulmões num barulho de catarata, cuja irrupção destruiria meus pulmões se o grito que quis dar não fosse um sonho.

... fizeram nascer em mim a imagem desse grito armado em guerra, desse terrível grito subterrâneo. Por esse grito, eu preciso cair.

É o grito do guerreiro fulminado que num barulho de vidros embriagado roça de passagem as muralhas quebradas.

Caio.

Caio mas não tenho medo.

Livro-me do barulho da raiva, num solene barrido.... Grito em sonho, mas sei que estou sonhando, e nos dois lados do sonho faço reinar minha vontade.

Grito numa armadura de ossos, nas cavernas de minha caixa torácica que, aos olhos perplexos de minha cabeça, assume uma importância desmedida.

Mas com esse grito fulminado, para gritar é preciso que eu caia.

Caio num subterrâneo e saio, não saio mais. (Artaud, 1964/2012, pp. 169-170)

O grito que ganha força em sua fraqueza se faz um caminho por onde escoa seus afetos. No buraco que o grito cava no sujeito, algo do inominável passa. O grito abre passagem, fura o corpo armadura para tentar fazer sobreviver à força de reinvindicação. É preciso cair para gritar, como diz o poeta. Da queda do sujeito, quando cai em um subterrâneo, é daí que o poeta nos narra sua existência. Na queda cria. Na produção artaudiana que se dá nesse subterrâneo psíquico, identifica-se um fazer com lalangue, a voz e o corpo. Nesse fazer, constrói-se a travessia do grito à fala. O grito, nesse cenário, pode irromper e se fazer ouvir. A hipótese é de que, ao tentar escrever o grito, Artaud operou com lalangue em sua obra. E, nessa operação, o grito pôde ser endereçado, permitindo com que a voz, ao tocar o peito do espectador, como desejava Artaud, se engatasse em um circuito que incluía o Outro.

\section{Scream writing in Antonin Artaud}

Abstract: This text arises from the listening-reading experience of the works of Antonin Artaud and brings together the testimony effects in the constructions of the poet about a moment of looseness between the voice and the word, giving rise to the scream. This study about the voice and attempts of writing the unspeakable leads to an accessory question about the body. In this structure, based on the psychoanalysis threads, lalangue - as a theoretical articulator encompassing body and word, voice and writing - stands out. Based on lalangue the essay is directed to the work of Artaud in order to travel along the scream path from the emptiness of the unanchored voice of the word in a moment of fall of the subject to a space/time of addressing and existence. Existence that will be supported and embodied in the work of Artaud.

Keywords: drive, voice, Antonin Artaud, lalangue. 


\section{Ecritures du cri chez Antonin Artaud}

Résumé : Ce texte parle de l'expérience de l'écoute-lecture de l'oeuvre d'Antonin Artaud et recueille dans les constructions du poète des effets de témoignage sur un temps de relâchement entre la voix et la parole, lorsque ce qui émerge est le cri. Cette étude concernant la voix et les tentatives d'écriture de ce qui est innommable nous conduit à une question subsidiaire sur le corps. Dans cette composition se démarque, à partir des fils de la psychanalyse, lalangue - articulateur théorique qui lie corps et parole, voix et écriture. C'est à partir de lalangue que l'article se penche vers l'oeuvre d'Artaud pour couvrir le passage du cridepuis le vide de la voix détachée de la parole, dans un moment de chute du sujet vers un espace/temps de directionnement et d'existence. Existence qui se soutiendra incarnée dans l'oeuvre d'Artaud.

Mots-clés : pulsion, voix, Antonin Artaud, lalangue.

\section{Escrituras del grito en Antonin Artaud}

Resumen: Este texto decanta de la experiencia de escucha-lectura de la obra de Antonin Artaud y recoge en las construcciones del poeta efectos de testimonio respecto a un tiempo de soltura entre voz y palabra, cuando lo que emerge es el grito. Este estudio sobre la voz y los intentos de escritura de lo innombrable conduce a una pregunta auxiliar sobre el cuerpo. En esa composición se sobresale, a partir de los hilos del psicoanálisis - lalangue - articulador teórico que enlaza cuerpo y palabra, voz y escritura. A partir de lalangue es que el artículo se inclina hacia la obra de Artaud para recorrer la travesía del grito desde el vacío de la voz desanclada de la palabra en un momento de caída del sujeto a un espacio/tiempo de direccionamiento y existencia. Existencia que se sostendrá corporificada en la obra de Artaud.

Palabras clave: pulsión, voz, Antonin Artaud, lalangue.

\section{Referências}

Artaud, A. (1977). Antonin Artaud: El Momo y outros poemas. Buenos Aires: Caldén.

Artaud, A. (1979). Textos de 1923 a 1946. Buenos Aires: Caldén. Artaud, A. (1980). Cartas desde Rodez, 3. Madrid: Fundamentos. Artaud, A. (1981). Cartas desde Rodez, 1. Madrid: Fundamentos. Artaud, A. (1986). Cartas desde Rodez, 2. Madrid: Fundamentos. Artaud, A. (2012). O teatro e seu duplo. São Paulo, SP: Martins Fontes. (Trabalho original publicado em 1964)

Artaud, A. (2014). O pesa-nervos. In J. Guinsburg, S. Telesi, \& A. Neto. (Orgs.), Linguagem e vida: Antonin Artaud (pp. 209-211). São Paulo, SP: Perspectiva. (Trabalho original publicado em 1925)

Assoun, P. L. (1999). O Olhar e a voz. Rio de Janeiro, RJ: Companhia de Freud.

Caldas, H. (2007). Da voz à escrita: clínica psicanalítica e literatura. Rio de Janeiro, RJ: Contra Capa.

Coêlho, W. (2013). Antonin Artaud: a linguagem na desintegração da palavra. Curitiba, PR: Appris.

Couso, O. M., Karoty, R., Aguirre, L., \& Mazza, C. (2010). Objeto a. Buenos Aires: Escola Freudiana de Buenos Aires.

Coutinho Jorge, M. A. (2011). Fundamentos da psicanálise: de Freud a Lacan. Rio de Janeiro, RJ: Zahar.

Del Barco, O. (Org.) (1979). Antonin Artaud. Textos 1923-1926. Buenos Aires: Caldèn.

Freud, S. (2006). Três ensaios sobre a teoria da sexualidade. In Edição standard brasileira das obras psicológicas completas de Sigmund Freud (J. Salomão, trad., Vol 7, pp. 119-231). Rio de Janeiro, RJ: Imago. (Trabalho original publicado em 1905)

Freud, S. (2006). Os instintos e suas vicissitudes. In Edição standard brasileira das obras psicológicas completas de Sigmund Freud (J. Salomão, trad., Vol. 14, pp. 117-144). Rio de Janeiro, RJ: Imago. (Trabalho original publicado em 1915)

Freud, S. (2006). Além do princípio do prazer. In Edição standard brasileira das obras psicológicas completas de Sigmund Freud (J. Salomão, trad., Vol. 18, pp. 12-75). Rio de Janeiro, RJ: Imago. (Trabalho original publicado em 1920)

Lacan, J. (1964-1965). El seminário, libro 12: problemas cruciales para el psicoanálisis (R. E. R. Ponte, trad.). Buenos Aires: Escuela Freudiana de Buenos Aires.

Lacan, J. (1985). O seminário, livro 20: mais, ainda, 1972-1973. Rio de Janeiro, RJ: Zahar.

Lacan, J. (1998). O seminário, livro 11: os quatro conceitos fundamentais da psicanálise, 1964. Rio de Janeiro, RJ: Zahar.

Lacan, J. (2002). O seminário, livro 3: as psicoses, 1955-1956. Rio de Janeiro, RJ: Zahar.

Lacan, J. (2016). O seminário, livro 6: o desejo e sua interpretação, 1958. Rio de Janeiro, RJ: Zahar.

Lacan, J. (2003). O aturdito. In Outros escritos (pp. 448-497). Rio de Janeiro, RJ: Zahar. (Trabalho original publicado em 1972) 
Lacan, J. (2005). Nomes-do-Pai. Rio de Janeiro, RJ: Zahar. (Trabalho original publicado em 1963)

Lacan, J. (2005) O seminário, livro 10: A angústia, 1962-1963. Rio de Janeiro, RJ: Zahar.

Lacan, J. (2007). O seminário, livro 16: De um Outro ao outro, 1968-1969. Rio de Janeiro, RJ: Zahar.

Lacan, J. (2007). O seminário, livro 23: O sinthoma, 1975-1976. Rio de Janeiro, RJ: Zahar.

Melman, C. (2008). Como alguém se torna paranoico? Porto Alegre, RS: CMC Editora.
Milner, J. C. (1987). O amor da língua. Porto Alegre, RS: Artes Médicas.

Násio, J. D., (1993). 5 Lições sobre a teoria de Jacques Lacan. Rio de Janeiro, RJ: Zahar.

Porge, E. (2014). Voz do eco. São Paulo, SP: Mercado de Letras.

Recebido: 09/07/18

Revisado: 03/08/20

Aprovado: 08/03/21 


\section{Errata}

No manuscrito "Escrituras do grito em Antonin Artaud", DOI: http://dx.doi.org/10.1590/0103-6564e180132, publicado no periódico Psicologia USP, volume 32, página 10:

\section{Onde se lia:}

Escrituras del grito en Antinin Artaud

\section{Leia-se:}

Escrituras del grito en Antonin Artaud 